\section{Kofi Agyekum}

Dr Kofi Agyekum, Lecturer, Department of Building Technology, Kwame Nkrumah University of Science and Technology, Kumasi, Ghana. Phone: +233 246761879 , email:<kagyekum.cap@ knust.edu.gh>

\section{Barbara Simons}

Dr Barbara Simons, Lecturer, Department of Building Technology, Kwame Nkrumah University of Science and Technology, Kumasi, Ghana. Phone: +233 243483224 , email: <nanaakuaayebea@ yahoo.co.uk>

\section{Seth Yeboah Botchway}

Mr Seth Yeboah Botchway, Graduate/Research Assistant, Department of Building Technology, Kwame Nkrumah University of Science and Technology, Kumasi, Ghana. Phone: +233 248637 501, email: <seth.botchway@ gmail.com>

DOI: http://dx.doi. org/10.18820/24150487/ as $25 \mathrm{i} 2.2$

ISSN: 1023-0564

e-ISSN: 2415-0487

Acta Structilia 2018 25(2): 39-61

(C) Creative Commons With Attribution (CC-BY)

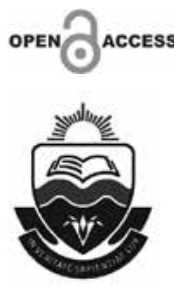

\section{Factors influencing the performance of safety programmes in the Ghanaian construction industry}

\section{Peer reviewed and revised}

*The authors declared no conflict of interest for this title or article

\begin{abstract}
Although proper safety management in construction is of prime importance, evidence from literature suggests that many developing countries do not consider safety adequately. This article examines the factors that influence the performance of safety management programmes in the Ghanaian Construction Industry. The objectives set to achieve this aim include identifying the safety elements incorporated in the safety programmes of construction firms, and determining the factors that negatively influence the performance of such elements. For objectivity, a quantitative survey was conducted among safety managers of $60 \mathrm{Dl}$ building construction firms located in the Kumasi and Greater Accra regions of Ghana. The questionnaire was structured into three parts, which sought the respondents' profile, identified the safety elements incorporated in the firms' safety programmes, and identified the factors that negatively influence the performance of the safety elements. Following a detailed literature review, the respondents were asked to rate 13 elements and 17 factors on a Likert scale. Data was analysed using the Statistical Package for Social Sciences (SPSS) Version 22. In addition to determining the reliability of the various constructs, the MSs, modes and standard deviations were obtained. The findings revealed that all of the 13 elements were incorporated in the firms' safety programmes. The key elements identified include 'providing safety managers on site'; 'providing written and comprehensive safety and health plans'; 'introducing project-specific training and regular safety meetings'; 'providing safety and
\end{abstract}


health orientation training', and 'involving employees in safety and evaluation'. The findings further revealed that 16 of the 17 factors negatively influence the performance of the firms' safety programmes. The identified factors were, among others, 'insufficient communication of safety programmes'; 'lack of workers' self-protection and awareness'; 'contractors ignoring safety, due to the time pressures of the project schedule'; 'poor personal attitudes towards safety', and 'ineffective laws and lack of enforcement'. Findings from this study should be useful to construction practitioners seeking to improve the safety records of their firms.

Keywords: Safety performance, safety programmes, safety elements, construction projects

\begin{abstract}
Abstrak
Alhoewel behoorlike veiligheidsbestuur in konstruksie van groot belang is, dui die bewyse uit die literatuur daarop dat baie ontwikkelende lande, veiligheid, nie genoeg oorweeg nie. Hierdie artikel ondersoek die faktore wat die prestasie van veiligheidsbestuursprogramme in die Ghanese Konstruksiebedryf beïnvloed. Die doelwitte wat gestel word om hierdie doel te bereik, sluit in die identifisering van die veiligheidselemente wat in die veiligheidsprogramme van konstruksiefirmas ingesluit is, en die bepaling van die faktore wat die prestasie van sulke elemente negatief beïnvloed. Vir objektiwiteit is ' $n$ kwantitatiewe opname onder veiligheidsbestuurders van $60 \mathrm{Dl}$ boukonstruksiefirmas in die Kumasi en Greater Accra-streke van Ghana gedoen. Die vraelys is in drie dele gestruktureer: Die respondente se profiel, die veiligheidselemente wat in die veiligheidsprogramme van die firmas opgeneem is, en die faktore wat die prestasie van die veiligheidselemente negatief beïnvloed. Na aanleiding van 'n gedetailleerde literatuuroorsig, is die respondente gevra om 13 elemente en 17 faktore op 'n Likert-skaal te gradeer. Data is geanaliseer met behulp van die SPSS Weergawe 22, Statistiese Pakket vir Sosiale Wetenskappe. Benewens die bepaling van die betroubaarheid van die verskillende konstrukte, is die MSs, modusse en standaardafwykings verkry. Die bevindings het getoon dat al die 13 elemente in die firmas se veiligheidsprogramme opgeneem is. Die sleutelelemente wat geïdentifiseer word, sluit in 'veiligheidsbeheerders op die terrein'; 'skriftelike en omvattende veiligheids- en gesondheidsplanne voorsien'; 'projekspesifieke opleiding en gereelde veiligheidsvergaderings bekendstel'; 'veiligheid en gesondheid oriëntering opleiding', en 'werknemers in veiligheid en evaluering'. Die bevindings het verder onthul dat 16 van die 17 faktore die prestasie van die firmas se veiligheidsprogramme negatief beïnvloed. Die geïdentifiseerde faktore was onder meer 'onvoldoende kommunikasie van veiligheidsprogramme'; 'gebrek aan werkers se selfbeskerming en bewustheid'; 'kontrakteurs ignoreer veiligheid, weens die tydsdruk van die projekskedule'; 'swak persoonlike houdings teenoor veiligheid', en 'oneffektiewe wette en gebrek aan handhawing'. Bevindings uit hierdie studie behoort nuttig te wees vir konstruksiepraktisyns wat die veiligheidsrekords van hul firmas wil verbeter.
\end{abstract}

Sleutelwoorde: Konstruksieprojekte, veiligheidsverrigting, veiligheidsprogramme, veiligheidselemente 
Agyekum, Simons \& Botchway • Factors influencing the performance...

\section{Introduction}

Several studies have been conducted on safety issues in the Ghanaian Construction Industry (GCl) (Mustapha, Aigbavboa \& Thwala, 2016: 11; Mustapha, 2016: 46; Kheni \& Braimah, 2014: 24; Dadzie, 2013: 35; Kheni, Gibb \& Dainty, 2010: 1104; Kheni, Dainty \& Gibb, 2008: 23). Some of these studies determine how the clauses on appropriate health and safety standards in the Labour Act 651 are used on construction sites (Dadzie, 2013: 36); others examine the institutional and legal environments relating to health and safety management in the construction industry (Kheni \& Braimah, 2014: 23), while still others examine the occupational health and safety implementation barriers (Mustapha, 2016: 46); improve occupational health and safety challenges (Mustapha, Aigbavboa \& Thwala, 2016: 11); develop a guidance framework for managing health and safety in Adaptive Retrofit Projects (Danso, Badu, Adadzie, Nani \& Manu, 2015: 73), and examine the influence of the contextual environment within which Ghanaian construction SMEs manage occupational health and safety (Kheni et al., 2010: 1104). A further study has established the existence of safety management programmes in the $\mathrm{GCl}$ (Yankah, 2012: 56).

Despite the safety management programmes in the $\mathrm{GCl}$, the rate at which accidents occur on construction sites keeps escalating (Danso et al., 2015: 73; Kheni \& Braimah, 2014: 24; Olutuase, 2014: 2; Dadzie, 2013: 36). Studies on effective safety management programmes in the vast majority of countries include and discuss the different elements in these programmes that help reduce the incident rates (LópezArquillos, Rubio-Romero, Carrillo-Castrillo \& Suarez-Cebador, 2015: 286). However, from the literature available, it is not known which safety programme elements are incorporated in the safety programmes in the $\mathrm{GCl}$. Neither is it known whether there are factors that negatively influence the performance of such safety programmes.

It is against this background that this study was initiated to examine the factors that influence the performance of safety management programmes in the $\mathrm{GCl}$. To achieve this aim, the study set out two objectives: to identify the safety programme elements incorporated in the safety programmes of construction firms, and to determine the factors that negatively influence the performance of safety programmes on construction sites. Identifying such factors will help management ensure that proper strategies are put in place to deal with such issues, which, in the long term, will cause a massive reduction in accidents that occur on GCls. 


\section{Literature review}

In order to understand the performance of safety management programmes in the $\mathrm{GCl}$, it is important to introduce the current theory on the safety management concepts included in this study. The existing theory focuses on the general state of health and safety management in the $\mathrm{GCl}$; construction safety management systems; programmes and their elements for construction safety, and factors that influence the performance of construction safety programmes.

\subsection{Health and safety management in the Ghanaian construction industry}

The GCl plays a vital role in achieving socio-economic development goals, providing shelter, infrastructure and employment, thus contributing significantly to the overall Gross Domestic Product (GDP) of the nation (Dadzie, 2013: 35; Anaman \& Osei-Amponsah, 2007: 4). The GCl relies heavily on labour-intensive methods. Coupled with the fact that construction work is carried out in constantly changing working environments, this poses significant health and safety risks such as injuries, accidents, and loss of skilled workers (Dadzie, 2013: 35; Cheng, Ryan \& Kelly, 2012: 363; Alhajeri, 201 1: 20; Fugar \& Agyakwah-Baah, 2010: 110; Kheni et al., 2010: 1104; Menzel \& Gutierrez, 2010: 180; Kheni et al., 2008: 23; Haslam Hide, Gibb, Gyi, Pavitt, Atkinson \& Duff 2005: 403). To deal with occupational health and safety issues, the Ghanaian government introduced several regulatory bodies that deal with safety issues occuring in all industries of Ghana (Annan, Addai \& Tulashie, 2015: 146). These regulatory bodies include: The Mining and Minerals Regulations $1970 \mathrm{LI} 665$; The Workman's Compensation Law 1987; The Ghana Health Services and Teaching Hospital Act 2003 (ACT 651); The Radiation Protection Instrument LI 1559 of 1993, an amendment of the Ghana Atomic Energy Act 204 of 1963, and The EPA Act 1994 (ACT 490) (Annan et al., 2015: 146).

Despite the vast literature recorded on the state of health and safety on construction sites in Ghana, no health and safety regulations have been specifically developed for the construction industry to date (Kheni \& Braimah, 2014: 24). However, the institutionalisation of the Factories, Offices and Shops Act 1970 made provision for a few sections dedicated to construction. The Act serves as a preventive measure for health and safety, in general (Dadzie, 2013: 35), and defines safety for factories, offices, shops, ports, and construction. The Act designates the minister for manpower, development and labour to make regulations in respect of construction works in order 
to address specific hazards (Kheni \& Braimah, 2014: 25). Section 57 of the Act is specifically directed at building and civil engineering works. Some of the relevant sections, as stated in Section 57(1), include: Sections 6 to 8 which require construction companies to register their sites and to report workplace accidents and dangerous occurrences to the Factory Inspectorate Department; Sections 10 to 12; Section 19 which requires companies to provide toilet facilities on site; Section 20 requires companies to provide wholesome drinking water on site; Section 25 requires companies to provide personal protective equipment for their workers and to take preventive measures to control or prevent specific hazards on sites, to Section 31. Other requirements are outlined in Sections 33 to 40; 43 to 54, and 60 to 87. In addition to the Factories, Offices and Shops Act 1970, the International Labour Organization's Code of Practice on Health and Safety on construction sites is also in operation in Ghana. The document provides guidelines in the implementation of the health and safety practice on construction sites for all workers. It also outlines the steps to be taken, including the provision of adequate welfare facilities; personal protective equipment appropriate for a job, and maintenance of a safe working environment for all workers on site (Dadzie, 2013: 35).

The above details clearly indicate that, although not complete, there is some form of institutional framework that ensures the proper monitoring and management of health and safety issues on construction sites in Ghana. However, according to Dadzie (2013: $35)$, the level of compliance with health and safety provisions in the Labour Act of Ghana is poor, since its adherence and practice on construction sites is low.

\subsection{Construction safety management systems}

Safety management relates to the actual practices, roles and functions that are associated with remaining safe (Kirwan, 1998: 72). Vinodkumar and Bhasi (2011: 499) infer that "safety management is regarded as a sub-system of the total organizational management, and it is usually carried out through an organization's safety management system with the aid of various safety management practices".

Safety management systems have been designed for different construction sites in different countries, and the safety factors included in such systems differ from one country to the other, mainly because of the cultural differences in the construction industries (Ismail, Doostdar \& Harun, 2012: 418; Ali, Abdullah \& Subramaniam, 
2009: 474; Aksorn \& Hadikusumo, 2008: 416; Fang, Xie, Huang \& Li, 2004: 45; Wokutch \& VanSandt, 2000: 370).

In the $\mathrm{GCl}$, effective safety management systems are usually made up of practices that comply with occupational health and safety requirements stipulated by the International Labour Organization (ILO) (Yankah, 2012: 56).

\subsection{Construction safety programmes}

The key objectives of adopting and implementing any construction safety programme is to avoid unacceptable behaviour that may cause accidents on site; to discover and report any unusual behaviour that may cause accidents, and to ensure that accidents are reported and handled properly (Abdelhamid \& Everett, 2000: 54; Al Haadir \& Panuwatwanich, 2011: 89). Henshaw (2004: 1) opines that effective safety programmes have trifold benefits such as protection of human life, cost reduction, and boost of employee morale and drive. Literature indicates that 'written safety policies', 'accident investigation and report', 'safety records', 'safety manuals', 'safety checklists', 'accident statistical analysis', 'formal safety organizational structure', 'safe inspection', 'safety training scheme', 'safe work practices', 'safety meetings', 'safety audit', 'safe promotion', 'safety committees at project sites', and 'safety committee at company' level are among the safety management programmes or practices that are put in place on construction sites (Wachter \& Yorio, 2014: 118; Ismail, Doostdar \& Harun, 2012: 420). In the quest to minimize the disruptions caused by accidents on sites, construction industries implement safety management programmes that seek to prevent the occurrence of accidents rather than essentially managing such accidents (Olutuase, 2014: 1). In general, construction firms that implement and follow the procedures set out in these programmes are expected to have highly safe construction sites and better project performance (Ismail, Doostdar \& Harun, 2012: 419; Olutuase, 2014: 2). Studies conducted by Hinze and Gambatese (2003: 162) and Findley, Smith, Kress, Petty \& Enoch (2004: 18) reveal that outstanding safety performance is closely related to construction projects where an operational safety programme is established, implemented and maintained.

Bottani, Monica and Vignali (2009: 157) reveal that, although safety management programmes are found to improve safety performance on construction sites, the majority of projects do not establish such systems on site. According to Cheng et al. (2012: 34), inadequate commitment to such safety management programmes 
on construction sites leads to reduced safety awareness among workers on the site. For such safety management programmes to be effective, competent safety personnel should be made responsible for determining and implementing the required preventive measures (Olutuase, 2014: 1).

\subsection{Elements of construction safety programmes}

López-Arquillos et al. (2015: 287) and Hallowell (2010: 28) confirm that construction safety programmes are made up of certain key safety elements such as 'upper management support'; 'employee involvement in safety and evaluation'; 'substance abuse programmes'; 'written and comprehensive safety and health plans'; 'project-specific training and regular safety meeting'; 'subcontractor selection and management'; 'job hazard analyses and communication'; 'recordkeeping and accident analyses'; 'emergency response planning'; 'safety and health committees'; 'safety manager on site'; 'safety and health orientation training', and 'frequent worksite inspections'. For the purposes of this study, these elements will be set as the key safety elements tested in safety programmes of participating construction firms. Table 1 introduces and describes these elements.

Table 1: Safety programme elements and descriptions

\begin{tabular}{|l|l|}
\hline \multicolumn{1}{|c|}{$\begin{array}{c}\text { Safety programme } \\
\text { element }\end{array}$} & \multicolumn{1}{c|}{ Description } \\
\hline $\begin{array}{l}\text { Upper management } \\
\text { support }\end{array}$ & $\begin{array}{l}\text { The upper management must be committed to ensuring } \\
\text { worker safety and health as the primary aim of a firm. } \\
\text { Such commitments must be demonstrated through } \\
\text { the participation in regular safety meetings, serving on } \\
\text { committees, and providing funding for other safety and } \\
\text { health programme elements. }\end{array}$ \\
\hline $\begin{array}{l}\text { Involvement of } \\
\text { employee in safety and } \\
\text { evaluation }\end{array}$ & $\begin{array}{l}\text { This entails the inclusion of all employees in the } \\
\text { formulation and execution of other programme } \\
\text { elements. With respect to health and safety activities, } \\
\text { employees can perform job hazard analysis, participate } \\
\text { in tools box talks, or perform inspections. Evaluating } \\
\text { employees' safety performance includes considering } \\
\text { safety metrics during regular employee performance } \\
\text { evaluations. }\end{array}$ \\
\hline $\begin{array}{l}\text { Substance abuse } \\
\text { programmes }\end{array}$ & $\begin{array}{l}\text { Being able to identify and prevent the abuse of } \\
\text { substances by workers. This includes random testing and } \\
\text { testing after injury. }\end{array}$ \\
\hline $\begin{array}{l}\text { Written and } \\
\text { comprehensive safety } \\
\text { and health plan }\end{array}$ & $\begin{array}{l}\text { A plan that documents project-specific safety and } \\
\text { health objectives, goals and methods for achieving } \\
\text { success. }\end{array}$ \\
\hline
\end{tabular}




\begin{tabular}{|l|l|}
\hline \multicolumn{1}{|c|}{$\begin{array}{c}\text { Safety programme } \\
\text { element }\end{array}$} & \multicolumn{1}{c|}{ Description } \\
\hline $\begin{array}{l}\text { Project-specific training } \\
\text { and regular safety } \\
\text { meeting }\end{array}$ & $\begin{array}{l}\text { Establishing and communicating project-specific safety } \\
\text { goals, plans and policies prior to the construction phase } \\
\text { of the project. }\end{array}$ \\
\hline $\begin{array}{l}\text { Subcontractor } \\
\text { selection and } \\
\text { management }\end{array}$ & $\begin{array}{l}\text { Considering safety and health performance during the } \\
\text { selection and management of subcontractors. }\end{array}$ \\
\hline $\begin{array}{l}\text { Job hazard analysis } \\
\text { and communication }\end{array}$ & $\begin{array}{l}\text { Reviewing and recording activities that are associated } \\
\text { with a construction process, highlighting potential } \\
\text { hazardous exposures, and documenting safe work } \\
\text { practices that prevent injury. }\end{array}$ \\
\hline $\begin{array}{l}\text { Record-keeping and } \\
\text { accident analysis }\end{array}$ & $\begin{array}{l}\text { Regularly reporting the specifics of all accidents, } \\
\text { including information such as time, location, work-site } \\
\text { conditions and cause. }\end{array}$ \\
\hline $\begin{array}{l}\text { Emergency response } \\
\text { planning }\end{array}$ & $\begin{array}{l}\text { A plan that documents a firm's policies and procedures } \\
\text { in case of a serious incident such as fatality. }\end{array}$ \\
\hline $\begin{array}{l}\text { Safety and health and } \\
\text { orientation training } \\
\text { committees }\end{array}$ & $\begin{array}{l}\text { Participation of all new hires or transfers in orientation } \\
\text { and training sessions that have a specific focus on safe } \\
\text { work practices and company safety policies. }\end{array}$ \\
\hline $\begin{array}{l}\text { Committees that have the power to effect changes } \\
\text { and set policies consist of a diverse group such } \\
\text { as supervisors, labourers, representatives of key } \\
\text { subcontractors, among others. }\end{array}$ \\
\hline $\begin{array}{l}\text { Employing a safety and health professional whose } \\
\text { primary responsibility is to perform and direct the } \\
\text { implementation of safety and health programme } \\
\text { elements and serve as a resource for employees. }\end{array}$ \\
\hline Sanger on site
\end{tabular}

Sources: López-Arquillos et al., 2015: 287; Hallowell, 2010: 28

A survey conducted among large construction firms in Ghana revealed that each of the firms admitted to having safety management programmes in place (Yankah, 2012: 72). However, there was no evidence of the various elements that were incorporated in such safety programmes, making it necessary to seek the views of practitioners on some key elements that are incorporated in the safety management programmes of construction firms. 
Agyekum, Simons \& Botchway • Factors influencing the performance...

\subsection{Factors that influence the performance of safety programmes}

The monitoring of safety performance programmes at all stages of construction projects is inevitable, because safety rules and regulations not only overcome issues such as poor quality work, unsafe working conditions, and lack of environmental control, but also reduce costs and enhance productivity (Wehbe, Hattab \& Hamzeh, 2016: 340; Koehn \& Datta, 2003: 565; Pheng \& Shiva, 2000: 32). Hsu, Su, Kao, Shu, Lin \& Tseng (2012: 6) define safety performance as the overall performance of the organisation's safety management system in terms of safe operation. Factors that influence the performance of safety programmes in the construction industry have been extensively studied. Studies conducted in Hong Kong, Kuwait, Uganda, China, Saudi Arabia, South Africa, Honduras, India, Malawi, and Jordan, among others, indicate that 'extensive subcontracting'; 'inadequate safety training'; 'absence of safety officers on site'; 'ineffective laws and lack of enforcement'; 'extensive use of foreign workers'; 'lack of workers' self-protection and awareness'; 'uncooperative clients and inadequate work procedures'; 'poor accident record-keeping', and 'lack of management commitment to safety budget allocation' are all factors that affect the performance of safety programmes (Irumba, 2014; 112; Alkilani, Jupp \& Sawhney, 2013: 150; Chiocha, Smallwood \& Emuze, 2011: 72; Al Humaidi \& Tan, 2010: 74; Zou \& Zhang, 2009: 623; Farooqui, Arif \& Rafeeqi, 2008: 78; Teo, Haupt \& Feng, 2008: 490; Gibb \& Bust, 2006: 77; Tam, Zeng \& Deng, 2004: 570). Yu, Ding, Zhou \& Luo (2004: 133) also suggest that 'lack of an emergency response plan which includes detailed response procedures; workers' unsafe operating of equipment and unsafe work practices', and 'contractors ignoring safety due to the time pressures of the project schedule' affect the performance of safety programmes. Other researchers also identified the following factors: poor personal attitudes (Fang, Chen \& Wong, 2006: 578); poor personal motivation (Johnson, 2003: 40); inadequate safety meetings (El-Mashaleh, Rababeh \& Hyari, 2009: 65); inefficient training and enforcement systems (Fang et al., 2006: 578; Toole, 2002: 206); poor equipment maintenance (Toole, 2002: 206); inadequate evaluation of programme (Abudayyeh, Fredericks, Butt \& Shaar, 2006: 167-174); insufficient communication (Abudayyeh et al., 2006: 169), and inadequate resource allocation (Abudayyeh et al., 2006: 169). Table 2 introduces and describes the various factors.

For the purposes of this study, these elements will be set as the factors tested for negatively influencing the performance of safety programmes in participating firms. 
Table 2: Factors that influence the performance of safety programmes and descriptions

\begin{tabular}{|c|c|c|}
\hline No. & $\begin{array}{l}\text { Factors influencing the } \\
\text { performance of safety } \\
\text { programmes }\end{array}$ & Description \\
\hline 1 & Extensive subcontracting & $\begin{array}{l}\text { Where the subcontractor(s) employed by the } \\
\text { main contractor do not have the needed } \\
\text { expertise to understand or is/are unwilling } \\
\text { to abide by the main contractor's safety } \\
\text { programmes. }\end{array}$ \\
\hline 2 & $\begin{array}{l}\text { Inefficient training and } \\
\text { enforcement systems }\end{array}$ & $\begin{array}{l}\text { Where new hires and old employees are } \\
\text { not given enough orientation and training } \\
\text { sessions that have a specific focus on safe } \\
\text { work practices and company safety policies. } \\
\text { Where employers, managers and supervisors } \\
\text { do not receive training on safety concepts } \\
\text { and their responsibility for protecting workers' } \\
\text { rights and responding to workers' reports and } \\
\text { concerns. }\end{array}$ \\
\hline 3 & $\begin{array}{l}\text { Absence of safety officers } \\
\text { on site }\end{array}$ & $\begin{array}{l}\text { Where there is no safety and health officer } \\
\text { to perform and direct the implementation of } \\
\text { safety and health programmes in the firm. }\end{array}$ \\
\hline 4 & $\begin{array}{l}\text { Ineffective laws and lack } \\
\text { of enforcement }\end{array}$ & $\begin{array}{l}\text { Where there are no written laws to document } \\
\text { project-specific safety and health goals and } \\
\text { objectives, and lack of enforcement of such } \\
\text { laws as a result of the absence of a safety } \\
\text { officer. }\end{array}$ \\
\hline 5 & $\begin{array}{l}\text { Extensive use of foreign } \\
\text { workers }\end{array}$ & $\begin{array}{l}\text { Extensively using or hiring workers who are not } \\
\text { originally employed by the firm and who do } \\
\text { not understand the firm's safety programmes. }\end{array}$ \\
\hline 6 & $\begin{array}{l}\text { Lack of workers' self- } \\
\text { protection and awareness }\end{array}$ & $\begin{array}{l}\text { Where the workers lack the necessary } \\
\text { knowledge on how to protect themselves } \\
\text { against injury or in case injury occurs. Workers } \\
\text { and their representatives are not involved } \\
\text { in all aspects of the programme, including } \\
\text { setting goals, identifying and reporting } \\
\text { hazards, and so on. }\end{array}$ \\
\hline 7 & $\begin{array}{l}\text { Uncooperative clients } \\
\text { and inadequate work } \\
\text { procedures }\end{array}$ & $\begin{array}{l}\text { Where management does not set } \\
\text { expectations for clients, managers, } \\
\text { supervisors, workers and for the overall } \\
\text { project. The overall work procedures are not } \\
\text { clearly outlined, and there are no specific } \\
\text { actions to improve worker safety and health. }\end{array}$ \\
\hline 8 & $\begin{array}{l}\text { Poor accident } \\
\text { record-keeping }\end{array}$ & $\begin{array}{l}\text { Poor or no reporting on the specifics of all } \\
\text { accidents, including information such as time, } \\
\text { location, worksite conditions and cause. }\end{array}$ \\
\hline
\end{tabular}




\begin{tabular}{|c|c|c|}
\hline No. & $\begin{array}{l}\text { Factors influencing the } \\
\text { performance of safety } \\
\text { programmes }\end{array}$ & Description \\
\hline 9 & $\begin{array}{l}\text { Lack of management } \\
\text { commitment to safety } \\
\text { budget allocation }\end{array}$ & $\begin{array}{l}\text { Management does not demonstrate its } \\
\text { commitment to eliminating hazards and } \\
\text { improving workplace safety and health. No } \\
\text { safety and health goals are established, } \\
\text { and there are inadequate provisions made } \\
\text { in terms of resources and support for the } \\
\text { programme. }\end{array}$ \\
\hline 10 & $\begin{array}{l}\text { Lack of an emergency } \\
\text { response plan }\end{array}$ & $\begin{array}{l}\text { There is no plan that documents a firm's } \\
\text { policies and procedures in case of a serious } \\
\text { incident such as fatality. }\end{array}$ \\
\hline 11 & $\begin{array}{l}\text { Contractors ignoring safety } \\
\text { due to the time pressures } \\
\text { of the project schedule }\end{array}$ & $\begin{array}{l}\text { Where management refuses to critically } \\
\text { follow its safety programmes, only because } \\
\text { the project is behind schedule. }\end{array}$ \\
\hline 12 & Poor personal attitudes & $\begin{array}{l}\text { Where all the workers, including the } \\
\text { contractors and temporary workers, duly } \\
\text { understand their roles and responsibilities } \\
\text { under the programme, but decide not to } \\
\text { follow as such. }\end{array}$ \\
\hline 13 & Poor personal motivation & $\begin{array}{l}\text { Where workers are not provided with the } \\
\text { equipment needed to carry out their various } \\
\text { activities. Where there are potential barriers } \\
\text { to workers' participation in the programme } \\
\text { (e.g., language, lack of information, } \\
\text { disincentives, and so on). }\end{array}$ \\
\hline 14 & $\begin{array}{l}\text { Inadequate safety } \\
\text { meetings }\end{array}$ & $\begin{array}{l}\text { Where there are no or hardly any safety } \\
\text { meetings to inform workers on any changes } \\
\text { or amendments in the safety programmes. }\end{array}$ \\
\hline 15 & $\begin{array}{l}\text { Poor equipment } \\
\text { maintenance }\end{array}$ & $\begin{array}{l}\text { Where the equipment used is poorly } \\
\text { maintained to the extent that it poses a } \\
\text { hazard to the potential users. }\end{array}$ \\
\hline 16 & $\begin{array}{l}\text { Inadequate evaluation of } \\
\text { safety programme }\end{array}$ & $\begin{array}{l}\text { Where control measures are not periodically } \\
\text { evaluated for effectiveness. There are no laid } \\
\text { down processes or procedures to monitor } \\
\text { the performance of the programmes, verify } \\
\text { the implementation of the programme, and } \\
\text { identify the shortcomings and opportunities } \\
\text { for improvement. Where there are no } \\
\text { necessary actions taken to improve the } \\
\text { programme and overall safety and health } \\
\text { performance. }\end{array}$ \\
\hline 17 & Insufficient communication & $\begin{array}{l}\text { Where management does not communicate } \\
\text { the hazards present at the worksite and the } \\
\text { hazards created on site by contract workers. } \\
\text { There is no coordination on work planning } \\
\text { and scheduling to identify and resolve any } \\
\text { conflicts that could impact on the safety } \\
\text { programme. }\end{array}$ \\
\hline
\end{tabular}




\section{Research methodology}

The purpose of this research was to examine the factors that influence the performance of safety management programmes in the $\mathrm{GCl}$, using a quantitative research approach. This approach allows for the use of structured questionnaire surveys, enabling researchers to generalise their findings from a sample of a population (Creswell, 2014; Hallowell, 2010: 27; Kheni et al. 2010: 1107). The questionnaire rated the elements incorporated in the safety programmes of construction firms as well as the factors that negatively influence the performance of these safety programmes. A quantitative research approach supports the use of interval Likert-type scales to measure data (Netemeyer, Bearden \& Sharma, 2003). Quantitative research also allows for the use of descriptive statistics to analyse data (Brown, 201 1: 11). Several data-analysis strategies are available. For this study, however, the MSs of interval data were used to calculate the central tendency in the data and to determine the composite (average) score of the Likert-type scale constructs (Nahm, 2016: 9; Jamieson, 2004: 1217).

\subsection{Sampling and response rate}

Building construction firms in Ghana should be registered according to the categories criteria set out by the Ghanaian Ministry of Water Resources, Works and Housing (MWRWH). The four categories of company classifications are $\mathrm{D}$ (building), $\mathrm{K}$ (civil engineering), $\mathrm{E}$ (electrical works), and $G$ (plumbing works) (Ayarkwa, Agyekum, Adinyira \& Osei-Asibey, 2012: 5). The MWRWH also provides four financial sub-classifications within these categories, namely Classes 1 (>500,000 USD), 2 (200,000 - 500,000 USD), 3 (75,000 - 200,000 USD) and 4 (>75,000 USD) (Asare-Yeboah, 2016: 10). These classifications set the limits for the companies with respect to their assets, plant and labour holdings, together with the nature and size of projects in which they can engage. Class 1 has the highest resource base, and decreases through Classes 2, 3 and 4 in that order (Ayarkwa et al., 2012: 5). For this study, D1 (building construction firms), located in the Kumasi and Greater Accra regions of Ghana, was used, because cities in these two regions serve as the hub for these large construction firms. The inclusion of a contractor's name in the MWRWH register is not compulsory (MWRWH, 2011). The snowball sampling approach was thus used to select a small population of known D1 individual firms from the MWRWH registry and expanded the sample by asking those initial participants to identify others that should participate in the study (Alvi, 2016: 35). The D1 firms in the sample were known to have some safety programmes in place, although such programmes 
do not clearly indicate the key elements outlined in Table 1. A list compiled from D1 firms resulted in a total sample of 60 firms used in this study.

\subsection{Data collection}

Using a face-to-face interview session, a structured questionnaire survey was conducted among safety managers of Dl building construction firms located in the Kumasi and Greater Accra regions of Ghana, from March 2017 to September 2017.

Topics on safety programmes used in the questionnaire were extracted from reviews of the literature, resulting in the formulation of a questionnaire divided into three sections. Section one on respondents' profile obtained demographic information on years of experience in the $\mathrm{GCl}$, number of projects involved in the $\mathrm{GCl}$, and availability of site safety programmes.

Section two is a set of 13 Likert-scale items on the construct safety programme elements (coded as SPE 1 to SPE 13) (see Table 1). Respondents were required to indicate their level of agreement on the inclusion of these elements in order to examine what safety programme elements are incorporated in the safety programmes of construction firms in Ghana.

Section three is a set of 17 Likert-scale items on the construct factors that influence the performance of safety programmes (coded as FSP 1 to FSP 17) (see Table 2). Respondents were required to indicate their level of agreement on these factors in order to examine if there are factors that negatively influence the performance of safety elements.

The data from these measurements forms the Likert-scale items used in the descriptive analysis of this study. To reduce the respondent's bias, closed-ended questions were preferred for sections 2 and 3 (Akintoye \& Main, 2007: 601). The questionnaire was administered to the study sample, along with a covering letter stating the purpose of the research, and the guarantee that the information given by the respondents would be treated as confidential and that no names would be mentioned in the research. Interview questionnaires were completed anonymously to ensure a true reflection of the respondents' views and to meet the ethical criterion of confidentiality. It was also assumed that the respondents were sincere in their responses because of their anonymity. 


\subsection{Analysis and interpretation of the data}

A 5-point interval Likert scale was used to measure how strongly respondents felt regarding the statements or questions in the Likertscale constructs. Likert scales are effective where numbers can be used to quantify the results of measuring behaviours, attitudes, preferences, and even perceptions (Wegner, 2012: 11; Leedy \& Ormrod, 2005: 185).

For the purposes of analysis, it is important to note that the scale intervals were equally distributed, where $1=$ not included/highly insignificant, 2 = least included/insignificant, 3 = neutral, 4 = included/ significant, and $5=$ highly included/highly significant.

Data was analysed using frequencies and MS rankings. For a factor to be considered significant, the MS should be 3.0 and above. To measure the existence of internal reliability in the Likert-type scales, the Cronbach's alpha coefficient was calculated and reported (Gliem \& Gliem, 2003: 88). Cronbach's alpha coefficient indicates the average correlation among all the items that make up the scale, in order to determine the reliability of the measuring instrument (Tavakol \& Dennick, 2011: 53; Maree \& Pietersen, 2007: 214). The alpha coefficient can range between 0 and 1 , where 1 = perfect internal reliability, and $0=$ no internal reliability (Pallant, 2011). For the purposes of this study, a minimum level of 0.5 was set as an acceptable level of internal reliability.

The Statistical Package for Social Sciences (SPSS) version 22 (Pallant, 2011) was used to calculate the Cronbach's alpha, to process the interval scales, and to analyse them using descriptive statistics such as means, modes, and standard deviations.

The frequencies and percentages of responses were generated and reported, in order to analyse the respondents' profile. The percentages, frequencies, mean, mode, and standard deviation of responses were generated, in order to analyse the safety elements incorporated. Only the mean of the items was reported to show the central tendency and to combine the MSs of the entire set of items in the construct to generate the composite (average) score for the elements.

The percentages, frequencies, mean, mode, and standard deviation of responses were generated, in order to analyse the factors that negatively influence the performance of the safety elements. Only the mean of the items was used to show the central tendency and to rank the factors in order of the most influential to the least influential. 
Agyekum, Simons \& Botchway • Factors influencing the performance...

\section{Results and discussion}

\subsection{Demography of respondents and firms}

Table 3 presents a summary of the demographic characteristics of the respondents and their firms. Experience is crucial when it comes to safety issues, in general. A large proportion (70\%) of the respondents had over 10 years' work experience in the $\mathrm{GCl}$, indicating their capability to provide well-informed responses. However, $30 \%$ of the respondents have between 1 and 10 years' work experience in the $\mathrm{GCl}$. The results further indicate that $80 \%$ of the respondents have been involved in 7 or more projects within the $\mathrm{GCl}$, enabling them to make knowledgeable contributions to issues pertaining to safety. The respondents further indicated that site safety programmes have been in place for all the projects in which they have been involved, thus confirming Yankah's (2012: 56) assertion.

Table 3: Demographic characteristics of respondents

\begin{tabular}{|l|c|c|}
\hline \multicolumn{1}{|c|}{ Demographic details } & Frequency & Percentage \\
\hline Number of years of experience in the GCl: & & \\
\hline $1-5$ years & 10 & $17 \%$ \\
\hline 6-10 years & 8 & $13 \%$ \\
\hline Over 10 years & 42 & $70 \%$ \\
\hline Number of projects involved in the GCl: & 2 & $3 \%$ \\
\hline $1-3$ & 10 & $17 \%$ \\
\hline $4-6$ & 20 & $33 \%$ \\
\hline 7-10 & 28 & $47 \%$ \\
\hline Above 10 & 60 & $100 \%$ \\
\hline Availability of site safety programmes: & 0 & $0 \%$ \\
\hline Yes & & \\
\hline No & & \\
\hline
\end{tabular}




\subsection{Safety programme elements incorporated in the firms' safety programmes}

This part of the research intended to identify the safety programme elements which the construction firms surveyed include in their safety programmes. Respondents had to rate the elements on a 5-point Likert scale, where 1 = not included, 2 = least included, 3 = neutral, $4=$ included, and $5=$ highly included; or 'unsure'. The data for the safety elements evaluated obtained a Cronbach's alpha score of 0.50 , which can be confirmed as reliable.

Although, at the initial stages of the questionnaire administration, the respondents had issues understanding the contents of these safety elements, a further description of the various elements (as indicated in Table 1) eased their doubts and facilitated their understanding and better answering of the questionnaire.

Table 4 shows the MSs, modes, and standard deviations of the various elements studied. The results reveal that the MSs of all the 13 safety programme elements evaluated by the respondents are significantly greater than the mean value of 3.0. Thus, in the opinion of the respondents, all the 13 elements are incorporated in the firms' safety programmes. The findings further reveal that 'providing safety managers on site'; 'providing written and comprehensive safety and health plans'; 'introducing project-specific training and regular safety meetings'; 'providing safety and health orientation training'; 'involving employees in safety and evaluation', and 'emergency response planning' are the six key elements introduced by the firms into their safety programmes. The remaining elements, including 'job hazard analyses and communication'; 'safety and health committees'; 'record-keeping and accident analyses'; 'subcontractor selection and management'; 'frequent worksite inspections'; 'upper management support', and 'substance abuse programmes' were all significant and, to some extent, also introduced in their safety programmes.

Table 4 shows that $57 \%$ of the respondents incorporated the element SPE 11 into their safety programmes. SPE 11 obtained a MS of 4.23, indicating that provision of safety managers on site is an element that is included in the safety programmes of the firms surveyed. A similar trend is observed in the elements SPE 4 and SPE 5, which had $78 \%$ and $50 \%$ of the respondents, respectively, indicating that such elements are incorporated in their safety programmes. The MSs of 3.90 and 3.87 obtained by these elements (SPE 4 and SPE 5) indicate that provision of 'written and comprehensive safety and health plans', and the provision of 'project-specific training and regular 
safety meetings' are further elements that are included in the safety programmes of the firms surveyed. The remainder of the elements (SPE 12, SPE 2, SPE 9, SPE 7, SPE 10, SPE 8, SPE 6, SPE 13, SPE 1, and SPE 3) saw a slight change in the respondents' views. For instance, $42 \%$ to $100 \%$ of the respondents were neutral about the incorporation of these elements (i.e., SPE 12, SPE 2, SPE 9, SPE 7, SPE 10, SPE 8, SPE 6, SPE 13, SPE 1, and SPE 3) in their safety programmes. This notwithstanding, those elements obtained MSs that were significantly greater than or equal to the mean value of 3.0 (see Table 4). Hence, they were considered as elements that were significantly included in the firms' safety programmes.

These findings simultaneously confirm and contradict those identified in other studies. For instance, a study conducted by Hallowell (2010: $30)$ reveals that not all the 13 elements were practised by construction organizations located within the USA. The majority (approximately $81 \%$ ) of such firms, however, implemented roughly 10 out of the 13 elements. This notwithstanding, some of the findings obtained in this section agree with those obtained by Hallowell (2010: 30).

Construction firms in the USA also considered elements such as 'regular written safety programmes'; 'emergency response plan', and 'project-specific training' that were incorporated in the safety programmes of Ghanaian construction firms (Hallowell, 2010: 30). However, elements such as employing a safety manager on site, which was ranked first in this study, was infrequently practised in the USA. Table 4 also shows that 'subcontractor selection and management' and 'upper management support' were ranked 10 and 12, respectively. Although incorporated, it was not given higher priority, thus agreeing well with Hallowell's (2010: 30) finding. The finding from this study further corroborates that of López-Arquillos et al. (2015: 289). In their study, job hazard analysis and communication, safety and health orientation training, and safety manager on site were all considered and implemented in safety programmes of civil engineering organizations located in Spain. The introduction of substance abuse programmes, which was considered the last option among construction firms in Ghana, were not considered significant at all by the firms in Spain. 


\begin{tabular}{|c|c|c|c|c|c|c|c|c|c|c|c|c|c|c|c|c|}
\hline & है & & - & $N$ & m & $\nabla$ & in & 0 & $\wedge$ & $\infty$ & $a$ & 으 & $=$ & $\simeq$ & $m$ & \\
\hline \multirow{11}{*}{ 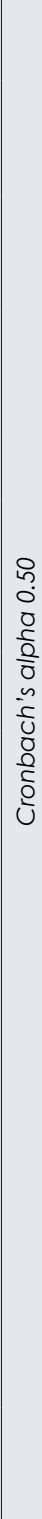 } & \multirow{3}{*}{ 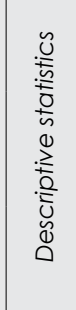 } & $\frac{0}{\dot{0}}$ & $\begin{array}{l}\text { ণू } \\
\text { Oे }\end{array}$ & $\begin{array}{l}\bar{\sigma} \\
\stackrel{0}{0}\end{array}$ & $\begin{array}{l}\stackrel{0}{\hat{0}} \\
0\end{array}$ & $\frac{N}{\hat{0}}$ & $\begin{array}{l}\infty \\
0 \\
0 \\
0\end{array}$ & $\begin{array}{l}0 \\
\stackrel{2}{0} \\
\circ\end{array}$ & $\begin{array}{l}\stackrel{2}{\alpha} \\
0 \\
0\end{array}$ & $\begin{array}{l}a \\
0 \\
0\end{array}$ & $\begin{array}{c}0 \\
\infty \\
0 \\
0\end{array}$ & $\stackrel{\text { ?n }}{\stackrel{0}{0}}$ & $\begin{array}{l}\Delta \\
\vdots \\
0\end{array}$ & $\begin{array}{l}\forall \\
\dot{0}\end{array}$ & $\begin{array}{l}8 \\
0\end{array}$ & \\
\hline & & $\begin{array}{l}\frac{\pi}{0} \\
\frac{0}{2}\end{array}$ & $\begin{array}{l}8 \\
\stackrel{+}{+}\end{array}$ & $\begin{array}{l}\stackrel{8}{\circ} \\
\dot{+}\end{array}$ & $\underset{+}{\stackrel{8}{8}}$ & $\begin{array}{l}\text { ○ } \\
\text { ले }\end{array}$ & $\begin{array}{l}8 \\
\dot{m}\end{array}$ & 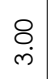 & $\begin{array}{l}\text { ৪ } \\
\dot{m}\end{array}$ & $\begin{array}{l}8 \\
\dot{m}\end{array}$ & $\begin{array}{l}\text { O } \\
\dot{m}\end{array}$ & $\begin{array}{l}\text { ৪ } \\
\dot{m}\end{array}$ & $\begin{array}{l}8 \\
\dot{m}\end{array}$ & $\begin{array}{l}\stackrel{\odot}{ } \\
\dot{m}\end{array}$ & $\begin{array}{l}\text { ○ } \\
\text { m. }\end{array}$ & \\
\hline & & $\begin{array}{l}\frac{1}{0} \\
d \\
\sum\end{array}$ & $\stackrel{\underset{\sim}{\sim}}{+}$ & $\begin{array}{l}\text { व } \\
\dot{m}\end{array}$ & $\begin{array}{l}\text { o. } \\
\text { ल. }\end{array}$ & $\stackrel{\circ}{\stackrel{\circ}{m}}$ & $\underset{n}{\tilde{m}}$ & 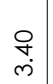 & $\begin{array}{l}\infty \\
m \\
m \\
m\end{array}$ & $\begin{array}{l}\stackrel{2}{N} \\
\text { mె }\end{array}$ & $\stackrel{\stackrel{\sim}{n}}{m}$ & $\frac{N}{m}$ & $\begin{array}{l}0 \\
0 \\
\dot{m}\end{array}$ & $\begin{array}{l}m \\
\dot{m} \\
\dot{m}\end{array}$ & $\begin{array}{l}8 \\
\text { ल. }\end{array}$ & 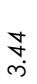 \\
\hline & \multirow{6}{*}{ 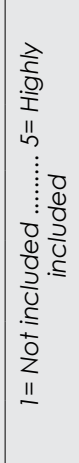 } & 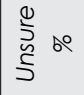 & 0 & 0 & 0 & 0 & 0 & 0 & 0 & 0 & 0 & 0 & 0 & 0 & 0 & \\
\hline & & ம চீ & 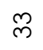 & $\wedge$ & 오 & $\stackrel{\infty}{-}$ & $\wedge$ & $\stackrel{\infty}{-}$ & $\stackrel{\infty}{-}$ & $n$ & $\simeq$ & 0 & $\sim$ & m & 0 & \\
\hline & & $\forall \measuredangle 0$ & no & $\stackrel{\infty}{\wedge}$ & ㅇํ & 우 & F & $\stackrel{\infty}{-}$ & 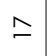 & $\stackrel{m}{N}$ & ㄱ. & $\stackrel{n}{-}$ & $\stackrel{n}{m}$ & 0 & 0 & \\
\hline & & $m$ চ & 으 & $m$ & సે & Y & $\stackrel{\infty}{q}$ & gे & 요 & $\hat{o}$ & 유 & 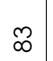 & $\infty$ & $\stackrel{2}{2}$ & 으 & \\
\hline & & $\sim \not \circ$ & 0 & $N$ & $m$ & 0 & m & $\stackrel{20}{-}$ & $\stackrel{2}{2}$ & $m$ & $\stackrel{\infty}{-}$ & 0 & $\stackrel{\infty}{-}$ & 0 & 0 & \\
\hline & & - চீ & 0 & 0 & 0 & 0 & 0 & 0 & 0 & $\sim$ & 0 & $\sim$ & $\wedge$ & $\sim$ & 0 & \\
\hline & & 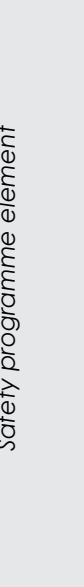 & 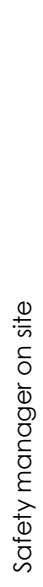 & 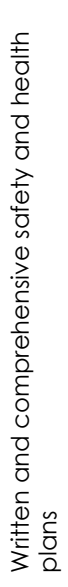 & 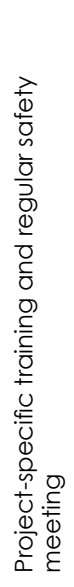 & 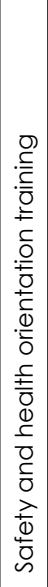 & 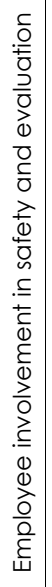 & 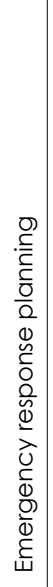 & 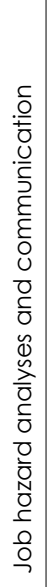 & 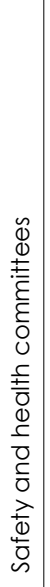 & 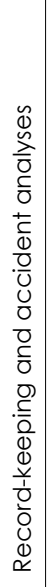 & 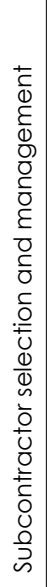 & 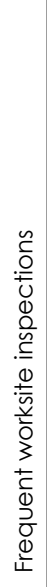 & 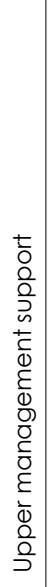 & 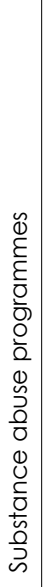 & 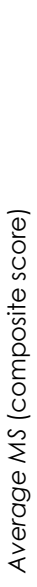 \\
\hline & & $\begin{array}{l}1 \\
0 \\
0 \\
U\end{array}$ & $\begin{array}{l}= \\
\frac{w}{n}\end{array}$ & 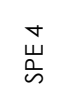 & 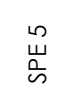 & $\begin{array}{l}\frac{N}{w} \\
\frac{\omega}{\omega}\end{array}$ & $\begin{array}{l}\stackrel{N}{u} \\
\stackrel{u}{\omega}\end{array}$ & $\begin{array}{l}a \\
\frac{w}{\omega}\end{array}$ & $\begin{array}{l}\hat{w} \\
\stackrel{\omega}{\omega}\end{array}$ & $\begin{array}{l}\frac{0}{u} \\
\underline{\underline{\Delta}} \\
\underline{s}\end{array}$ & $\begin{array}{l}\infty \\
w \\
\tilde{D}\end{array}$ & $\begin{array}{l}0 \\
\stackrel{u}{\omega} \\
\dot{\omega}\end{array}$ & $\begin{array}{l}\frac{m}{w} \\
\frac{w}{\omega}\end{array}$ & $\begin{array}{l}\bar{w} \\
\dot{\omega}\end{array}$ & $\begin{array}{l}m \\
w \\
\sim \\
\sim\end{array}$ & \\
\hline
\end{tabular}


Table 4 indicates a composite score (average MS) of 3.44 for the safety programme elements, indicating that, on the mean evaluation scale, respondents generally "agree" that these elements should be incorporated in the safety programmes of construction firms in Ghana.

The differences between some of the findings in this study compared to those of Hallowell (2010: 30) and López-Arquillos et al. (2015: 289) are purely due to the differences in organizational culture. USA and Spain are developed countries, whereas Ghana is a developing country. As a result, the cost associated with the implementation of some of these elements is higher in the developed country than in a developing country. This is well iterated by Hallowell (2010: 30) who found that elements such as 'employing a site-specific safety manager'; 'inspections and trainings', and 'regular safety meetings' were the three most expensive and costly safety programme elements as defined in dollars in investment per million dollars of project scope. These three elements were, however, among the first five elements incorporated in the safety programmes of Ghanaian construction firms.

\subsection{Factors that negatively influence the performance of safety programmes}

This part of the research also intended to identify the factors that negatively influence the performance of safety programmes among the construction firms surveyed. Respondents had to rate the elements on a 5 -point Likert scale, where $1=$ highly insignificant, $2=$ insignificant, 3 = neutral, 4 = significant, and 5 = highly significant; or 'unsure'. The data for the factors evaluated obtained a Cronbach's alpha score of 0.70 , which can be confirmed as reliable.

The various factors that negatively influence the performance of the safety programmes were described (see Table 2) to ease the respondents' doubts, thus facilitating their understanding and better answering of the questionnaire.

The results shown in Table 5 reveal that the MSs of 16 out of the 17 factors evaluated by the respondents are significantly greater than the mean value of 3.0. Thus, in the respondents' opinion, 16 of the 17 factors negatively influence the performance of safety programmes. The findings further reveal the 6 key factors that negatively influence the performance of safety programmes, namely 'insufficient communication'; 'lack of workers' selfprotection and awareness'; 'contractors ignoring safety due to the time pressures of the project schedule'; 'poor personal attitudes'; 
'ineffective laws and lack of enforcement', and 'poor equipment maintenance'. The remaining factors, including 'inadequate safety meetings'; 'inadequate evaluation of safety programme'; 'lack of an emergency response plan'; 'lack of management commitment to safety budget allocation'; 'poor accident recordkeeping'; 'uncooperative clients and inadequate work procedures'; 'extensive use of foreign workers'; 'absence of safety officers on site'; 'inefficient training and enforcement systems', and 'extensive subcontracting', were also considered to negatively influence the performance of the safety programmes. The respondents were, however, not in agreement with 'poor personal motivation' being an influencing factor.

Table 5 shows that 9 of the 17 factors received maximum percentage rating by the respondents as significant factors that influence the performance of safety programmes in the firms surveyed. These factors include FSP 17 (rated by $17 \%$ of the respondents as significant), FSP 12 (50\%), FSP 4 (40\%), FSP 14 (48\%), FSP 16 (78\%), FSP 10 (52\%), FSP 9 (60\%), FSP 5 (42\%), and FSP $3(40 \%)$. All these factors obtained MSs greater than the mean value of 3.00 , indicating that such factors significantly affected the performance of safety programmes in the firms. Four of the 17 factors also received maximum percentage rating by the respondents as highly significant factors that influence the performance of safety programmes. These factors include FSP 6 (56\%), FSP 11 (53\%), FSP 15 (47\%), and FSP 8 (33\%). These factors obtained MSs of 4.52,4.43,4.06, and 3.63, respectively, indicating the significance of such factors in negatively influencing the performance of safety programmes. Furthermore, 3 of the 17 factors received maximum rating by the respondents as neutral. These factors include FSP 7(37\%), FSP 2 (60\%), and FSP 1 (77\%). Although the respondents rated these factors on the neutral bases, it can be noted that the MSs of all the three factors were above the mean value of 3.00, an indication that such factors negatively influenced the performance of safety programmes. The respondents rated factor FSP 13 as insignificant, with a percentage rating of 55\%, highly reflective of its MS being lower than the mean value of 3.0.

Studies conducted in Hong Kong, Kuwait, Uganda, China, Saudi Arabia, and South Africa (Irumba, 2014: 112; Al Humaidi \& Tan, 2010: 74; Zou \& Zhang, 2009: 623; Teo et al., 2008: 490; Tam et al., 2004: 570) revealed that 'extensive subcontracting' and 'absence of adequate safety training' were among the key factors influencing the performance of safety programmes in the construction industry. 
However, in the current study (Table 5), 'extensive subcontracting' and 'absence of adequate safety training' (in this case, inefficient safety training and enforcement systems) were ranked 16 and 15, respectively. This indicates that, although the construction organizations in Ghana view these factors as possible influencing factors of safety programme performance, they were not that much of a threat. Table 4 explains this and indicates that 'subcontractor selection and management' and 'safety and health orientation training' were, to some extent, incorporated in safety programmes of construction firms in Ghana. In countries such as Honduras, India, Malawi and Jordan, factors such as 'absence of safety officers on site' and 'ineffective laws and lack of enforcement' were viewed as influencing the performance of safety programmes on site (Alkilani et al., 2013: 150; Chiocha et al., 2010: 72), because the researchers agree with Hallowell (2010: 31 ) that it is expensive to implement such elements in the safety programmes. In the current study (Table 5), it is revealed that 'absence of safety officers on site' and 'ineffective laws and lack of enforcement' were ranked 14 and 5, respectively.

Table 5 (next page) indicates a composite score (average MS) of 3.83 for the factors that influence the performance of safety programmes, indicating that, on the mean evaluation scale, respondents generally "agree" that these factors might influence the performance of safety programmes in the $\mathrm{GCl}$.

The absence of safety officers on site, being ranked 14, depicts the reason why it is among the elements incorporated in safety programmes in Ghana. However, for the respondents to indicate that 'ineffective laws and lack of enforcement' (Table 5) is a key factor that influences the performance of safety programmes in the $\mathrm{GCl}$ needs attention. In Kuwait, Pakistan, China, Jordan, Botswana, Egypt, Nigeria, South Africa, Malawi, and so on, factors such as 'extensive use of foreign workers'; 'lack of workers' self-protection and awareness'; 'uncooperative clients and inadequate work procedures'; 'poor accident record-keeping', and 'lack of management commitment to safety budget allocation' were all viewed as factors influencing the performance of safety programmes in the construction industry. This corroborates the findings from this study. 


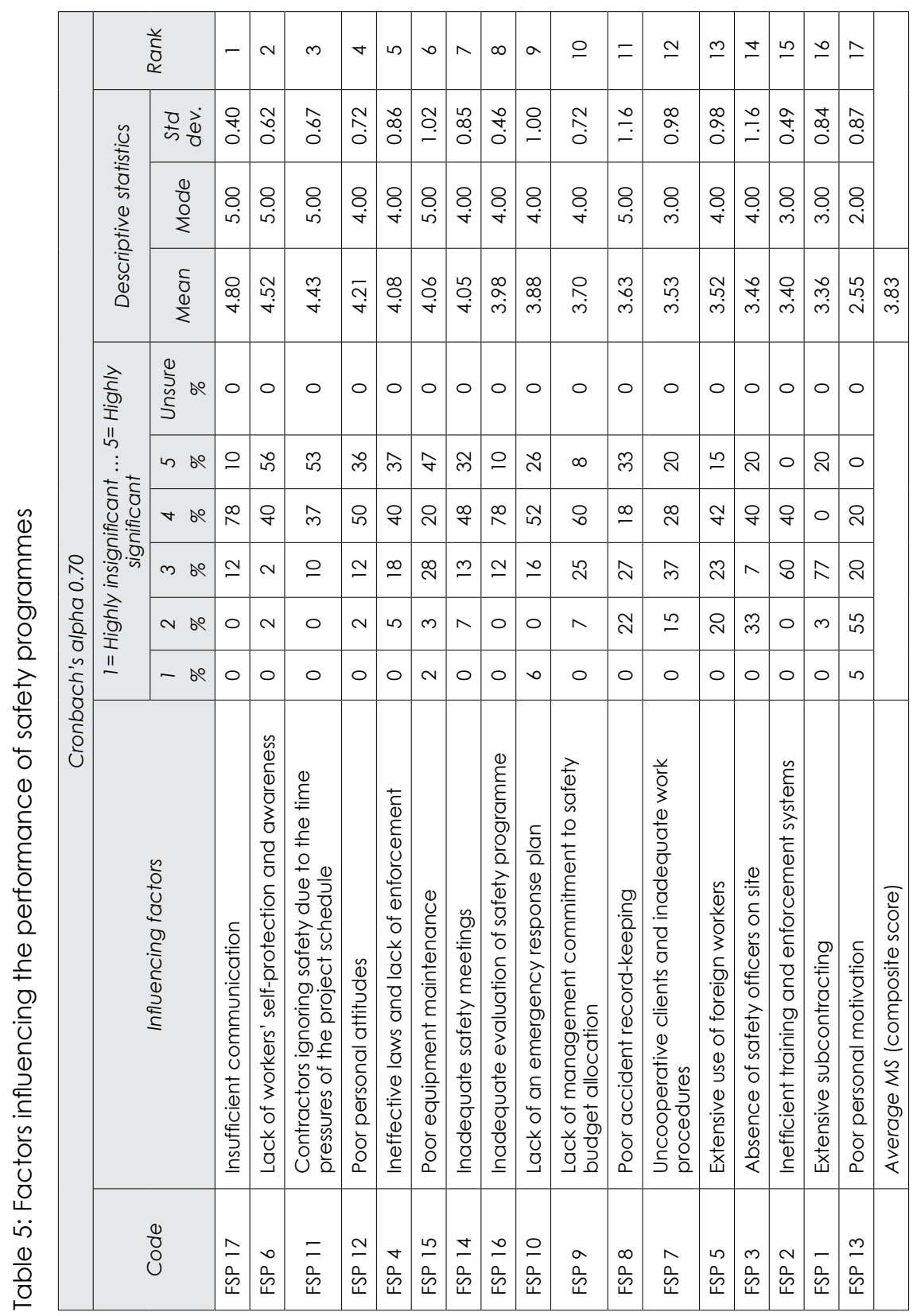




\section{Conclusion}

Numerous studies have been conducted on health and safety issues in the $\mathrm{GCl}$. However, in the absence of empirical studies to examine the influencing factors against the performance of safety programmes, this study was conducted to fill a necessary gap. The study sought to examine the factors that influence the performance of safety management programmes in the $\mathrm{GCl}$. To achieve this aim, the study set out two objectives: to identify the safety programme elements incorporated in the safety programmes of construction firms and to determine the factors that negatively influence the performance of such elements.

With respect to the first objective, the respondents agreed that all the 13 elements were incorporated in the safety programmes of the firms surveyed. It was further revealed that 'providing safety managers on site'; 'providing written and comprehensive safety and health plans'; 'introducing project-specific training and regular safety meetings'; 'providing safety and health orientation training'; 'involving employees in safety and evaluation', and 'emergency response planning' are the six key elements introduced by Ghanaian construction firms in their safety programmes.

With respect to the second objective, the findings revealed that 16 of the 17 factors, which the respondents evaluated, negatively affected the performance of safety programmes on construction sites. It was also revealed that 'insufficient communication of safety programmes'; 'lack of workers' self-protection and awareness'; 'contractors ignoring safety due to the time pressures of the project schedule'; 'poor personal attitudes towards safety'; 'ineffective laws and lack of enforcement', and 'poor equipment maintenance' are the six key factors that negatively influence the performance of safety programmes. This study provides a broad perspective on the issues that hinder the development of safe working practices in the GCl. Currently, in Ghana, although the majority of first-class construction companies have safety programmes in place, it is not clear which key safety elements have been incorporated in such programmes. The safety elements identified in this study gave insight into which elements are of priority to such construction companies. Identifying the factors that negatively influence the performance of the safety programmes should be useful to construction practitioners seeking to improve the safety records of their firms. 


\section{Limitation of the study}

Although the objectives set out in this article were duly achieved, there are some limitations. Key among the limitations was the relatively small sample size of the respondents (in this case, 60 construction firms). This small sample size is attributed to the limitation in getting access to up-to-date information on registered building construction firms in good standing in Ghana. This means that, although the current findings can reflect the current state of safety issues in the $\mathrm{GCl}$, the views of other relevant firms may not have been included. Future studies could be carried out to include other relevant construction firms that may have been excluded from the current study. Since performance is a two-way issue and this study only considered those factors that negatively influence performance, a future study could be conducted to determine how the performance of the various factors could be improved.

\section{References}

Abdelhamid, T.S. \& Everett J.G. 2000. Identifying root causes of construction accidents. Journal of Construction Engineering and Management, 126(1), pp. 52-60. https://doi.org/10.1061/ (ASCE)0733-9364(2000) 126:1 (52)

Abudayyeh, O., Fredericks, T., Butt, S. \& Shaar, A. 2006. An investigation of management's commitment to construction safety. International Journal of Project Management, 24(2), pp. 167-174. https://doi. org/10.1016/j.jproman.2005.07.005

Akintoye, A. \& Main, J. 2007. Collaborative relationships in construction: The UK contractor's perception. Engineering, Construction and Architectural Management, 14(6), pp. 597-617. https://doi. org/10.1 108/09699980710829049

Aksorn, T. \& Hadikusumo, B.W.H. 2008. Critical success factors influencing safety program performance in Thai construction projects. Safety Science, 46(4), pp. 709-727. https://doi.org/10.1016/j.ssci.2007.06.006

Al Haadir, S. \& Panuwatwanich, K. 2011 . Critical success factors for safety programme implementation among construction companies in Saudi Arabia. Procedia Engineering, 14(2011), pp. 148-155. https:// doi.org/10.1016/j.proeng.2011.07.017

Alhajeri, M. 2011. Health and safety in the construction industry: Challenges and solutions in the UAE. Unpublished PhD thesis, Coventry, UK: Coventry University. 
Al Humaidi, H.M. \& Tan, H.M. 2010. Construction safety in Kuwait. Journal of Performance in Constructed Facilities, 24(1), pp. 70-77. https://doi.org/10.1061/(ASCE)CF.1943-5509.0000055

Ali, H., Abdullah, N.A.C. \& Subramaniam, C. 2009. Management practice in safety culture and its influence on workplace injury. Disaster Prevention and Management, 18(5), pp. 470-477. https://doi. org/10.1108/09653560911003660

Alkilani, S.Z., Jupp, J. \& Sawhney, A. 2013. Issues of construction health and safety in developing countries: A case of Jordan Australasian. Journal of Construction Economics and Buildings, 13(3), pp. 141-156. https://doi.org/10.5130/AJCEB.v13i3.3301

Alvi, M.H. 2016. A manual for selecting sampling techniques in research. Pakistan: University of Karachi, Iqra University.

Anaman, K.A. \& Osei-Amponsah, C. 2007. Analysis of causality links between the growth of the construction industry and growth of the macro-economyin Ghana.ConstructionManagementandEconomics, 25(9), pp. 951-961. https://doi.org/10.1080/01446190701411208

Annan, J.S., Addai, E.K. \& Tulashie, S.K. 2015. A call for action to improve occupational health and safety in Ghana and a critical look at the existing legal requirement and legislation. Safety and Health at Work, 6(2), pp. 146-150. https://doi.org/10.1016/j.shaw.2014.12.002

Asare-Yeboah, K. 2016. Best practice: Procurement of contracting and engineering services. Speech delivered at CESA Infrastructure Indaba, Durban, South Africa, 7 November. [online]. Available at: <http:// www.cesa.co.za/sites/default/files/20161107_S3_2_Procuring\%20 Contracting\%20\&\%20Engineering\%20Services\%20_Best\%20Practices_ Ing\%20K\%20Asare-Yeboah.pdf> [Accessed: 12 June 2017].

Ayarkwa, J., Agyekum, K., Adinyira, E. \& Osei-Asibey, D. 2012. Barriers to successful implementation of lean construction in the Ghanaian building industry. Journal of Construction, 5(1), pp. 3-11.

Bottani, E., Monica, L. \& Vignali, G. 2009. Safety management systems: Performance differences between adopters and non-adopters. Safety Science, 47(2009), pp. 155-162. https://doi.org/10.1016/j. ssci.2008.05.001

Brown, J.D. 2011. Likert items and scales of measurement? JAL Testing \& Evaluation SIG Newsletter, 15(1), pp. 10-14.

Cheng, E.W.L., Ryan, N. \& Kelly, S. 2012. Exploring the perceived influence of safety management practices on project performance 
in the construction industry. Safety Science, 50(2), pp. 363-369. https:// doi.org/10.1016/j.ssci.2011.09.016

Chiocha, C., Smallwood, J. \& Emuze, F. 2011. Health and safety in the Malawian construction industry. Acta Structilia, 18(1), pp. 68-80.

Creswell, J.W. 2014. Research design: Qualitative, quantitative and mixed methods approaches. $4^{\text {th }}$ edition. Thousand Oaks, CA: Sage.

Dadzie, J. 2013. Perspectives of consultants on health and safety provisions in the Labour Act: A study into theory and practical. Engineering Management Research, 2(1), pp. 34-42. https://doi. org/10.5539/emr.v2n1p34

Danso, F.O., Badu, E., Adadzie, D.K., Nani, G. \& Manu, P. 2015. Towards a framework for the management of health, safety and well-being on adaptive-retrofit projects in Ghana. In: Arcom Doctoral Workshop Health, Safety and Wellbeing, Edinburgh, Scotland, UK, 11 February 2015.

El-Mashaleh, M.S., Rababeh, S.M. \& Hyari, K.H. 2009. Utilizing data envelopment analysis to benchmark safety performance of construction contractors. International Journal of Project Management, 28(1), pp. 61-67. https://doi.org/10.1016/j.jproman.2009.04.002

Fang, D., Chen, Y. \& Wong, L. 2006. Safety climate in construction industry: A case study in Hong Kong. Journal of Construction Engineering and Management, 132(6), pp. 573-584. https://doi. org/10.1061/(ASCE)0733-9364(2006) 132:6(573)

Fang, D.P., Xie, F., Huang, X.Y. \& Li, H. 2004. Factor analysis-based studies on construction workplace safety management in China. International Journal of Project Management, 22(1), pp. 43-49. https:// doi.org/10.1016/S0263-7863(02)00115-1

Farooqui, R.U., Arif, F. \& Rafeeqi, S.F. 2008. Safety performance in construction industry of Pakistan. In: Proceedings of the First International Conference on Construction in Developing Countries, Karachi, Pakistan, 4-5 August, pp. 74-87.

Findley, M., Smith, S.M., Kress, T., Petty, G. \& Enoch, K. 2004. Safety program elements in construction: Which ones best prevent injuries and control related workers' compensation costs? Professional Safety, 49(2) pp. 14-21.

Fugar, F.G.K. \& Agyakwa-Baah, A.B. 2010. Delays in building construction projects in Ghana. Australian Journal of Construction Economics and Building, 10(1/2), pp. 103-1 16. https://doi.org/10.5130/ ajceb.v10i1/2.1592 
Agyekum, Simons \& Botchway • Factors influencing the performance...

Gibb, A. \& Bust, P. 2006. Construction health and safety in developing countries. Loughborough, Great Britain: European Construction Institute.

Gliem, R. \& Gliem, J. 2003. Calculating, interpreting, and reporting Cronbach's alpha reliability coefficient for Likert-type scales. In: Midwest Research-to-Practice Conference in Adult, Continuing, and Community Education, The Ohio State University, Columbus, $\mathrm{OH}, 8-10$ October, pp. 82-88.

Hallowell, M. 2010. Cost-effectiveness of construction safety programme elements. Construction Management and Economics, 28(1), pp. 25-34. https://doi.org/10.1080/01446190903460706

Haslam, R.A., Hide, S.A., Gibb, A.G.F., Gyi, D.E., Pavitt, T., Atkinson, S. \& Duff, A.R. 2005. Contributing factors in construction accidents. Applied Ergonomics, 36(4), pp. 401-415. https://doi.org/10.1016/j. apergo.2004.12.002

Henshaw, J.L. 2004. Safety and health add value to your business, workplace and life. In: Proceedings of the $8^{\text {th }}$ Biennial Governors Pacification Rim Safety and Health Conference, 13-14 September 2004, Ochu, Hawaii.

Hinze, J. \& Gambatese, J. 2003. Factors influencing safety performance of specialty contractors. Journal of Construction Engineering and Management, 129(2), pp. 159-164. https://doi.org/10.1061/ (ASCE)0733-9364(2003) 129:2(159)

Hsu, I.Y., Su, T.S., Kao, C.S., Shu, Y.L., Lin, P.R. \& Tseng, J.L. 2012. Analysis of business safety performance by structural equation models. Safety Science, 50(2012), pp. 1-11. https://doi.org/10.1016/j.ssci.2011.04.012

Irumba, R. 2014. Spatial analysis of construction accidents in Kampala, Uganda. Safety Science, 64 (2014), pp. 109-120. https://doi. org/10.1016/j.ssci.2013.11.024

Ismail, Z., Doostdar, S. \& Harun, Z. 2012. Factors influencing the implementation of a safety management system for construction sites. Safety Science, 50(2012), pp. 418-423. https://doi.org/10.1016/j. ssci.2011.10.001

Jamieson, S. 2004.Likertscales:Howto (ab)usethem.MedicalEducation, 38(12), pp. 1212-1218. https://doi.org/10.1111/j.1365-2929.2004.02012.x

Johnson, S.E. 2003. Behavioural safety theory: Understanding the theoretical foundation. Journal of Professional Safety, 48(10), pp. 39-44.

Kheni, N.A. \& Braimah, C. 2014. Institutional and regulatory frameworks for health and safety administration: Study of the construction industry in Ghana. International Refereed Journal of Engineering and Sciences, 3(2), pp. 24-34. 
Kheni, N.A., Gibb, A.G.F. \& Dainty, A.R.J. 2010. Health and safety management within small and medium-sized enterprises (SMEs) in developing countries: Study of contextual influences. Journal of Construction Engineering and Management, 136(10), pp. 1104-1115. https://doi.org/10.1061/(ASCE)CO.1943-7862.0000218

Kheni, N.A., Dainty, A.R.J. \& Gibb, A.G.F. 2008. Health and safety management in developing countries: A study of construction SMEs in Ghana. Construction Management and Economics, 26(11), pp. 1159-1169. https://doi.org/10.1080/01446190802459916

Kirwan, B. 1998. Safety management assessment and task analysis - a missing link? In: Hale, A. \& Baram, M. (Eds), Safety management: The challenge of change. Oxford, UK: Elsevier, pp. 67-92.

Koehn, E.E. \& Datta, N.K. 2003. Quality, environmental, and health and safety management systems for construction engineering. Journal of Construction Engineering and Management, 129(5), pp. 562-569. https://doi.org/10.1061/(ASCE)0733-9364(2003) 129:5(562)

Leedy, P.D. \& Ormrod, J.E. 2005. Practical research: Planning and design. $8^{\text {th }}$ edition. Harlow: Pearson.

López-Arquillos, A., Rubio-Romero, J.C., Carrillo-Castrillo, J. \& SuarezCebador, M. 2015. Effectiveness of construction safety programme elements. In: Cortes, P., Maeso-Gonzales, E. \& Escudero-Santana, A. (Eds). Proceedings, Enhancing synergies in a collaborative environment. Lecture Notes in Management and Industrial Engineering, Switzerland: Springer International Publishing, pp. 285-289. https://doi. org/10.1007/978-3-319-14078-0_32

Maree, K. \& Pietersen, J. 2007. The quantitative research process. In: Maree, K. (Ed.). First steps in research. Pretoria: Van Schaik, pp. 145-153.

Menzel, N.N. \& Gutierrez, A.P. 2010. Latino worker perceptions of construction risks. American Journal of Industrial Medicine, 53(2), pp. 179-187. https://doi.org/10.1002/ajim.20735

Mustapha, Z. 2016. Revised health and safety compliance model for the Ghanaian construction industry. International Journal of Engineering, Science and Technology, 8(2), pp. 46-51. https://doi. org/10.4314/ijest.v8i2.4

Mustapha, Z., Aigbavboa, C. \& Thwala, W.D. 2016. Occupational health and safety challenges in Ghana: The way forward. In: Whala, W.D. \& Aigbavboa, C.O. (Eds). Proceedings of the International Conference on Infrastructure Development in Africa, 10-12 July, Johannesburg, South Africa, pp. 11-15. 
MWRWH (Ministry of Water Resource, Works and Housing). 2011. List of registered building contractors in Ghana. [online]. Available at: <http://www.mwrwh.gov.gh/index.php/classification> [Accessed: 18 June 2017].

Nahm, F.S. 2016. Nonparametric statistical tests for the continuous data: The basic concept and the practical use. Korean Journal of Anesthesiology, 69(1), pp. 8-14.https://doi.org/10.4097/kjae.2016.69.1.8

Netemeyer, R.G., Bearden, W.O.E. \& Sharma, S. 2003. Scaling procedures: Issues and applications. Thousand Oaks, CA: Sage. https://doi.org/10.4135/9781412985772

Olutuase, S.O. 2014. A study of safety management in the Nigerian construction industry. IOSR Journal of Business and Management, 16(3), pp. 1-10. https://doi.org/10.9790/487X-16350110

Pallant, J. 2011 . A step by step guide to data analysis using SPSS program survival manual. $4^{\text {th }}$ edition. Crow's Nest, Australia: Allen \& Unwin.

Pheng, L.S. \& Shiva, S.C. 2000. The maintenance of construction safety: Riding on ISO 9000 quality management systems. Journal of Quality in Maintenance Engineering, 6(1), pp. 28-44. https://doi. org/10.1108/13552510010311327

Tam, C.M., Zeng, S.X. \& Deng, Z.M. 2004. Identifying elements of poor construction safety management in China. Safety Science, 42(7), pp. 569-586. https://doi.org/10.1016/j.ssci.2003.09.001

Tavakol, M. \& Dennick, R. 2011. Making sense of Cronbach's alpha. International Journal of Medical Education, 2, pp. 53-55. https://doi. org/10.5116/ijme.4dfb.8dfd

Teo, A.L., Haupt, T.C. \& Feng, Y. 2008. Construction health and safety performance in developing and developed countries: A parallel study in South Africa and Singapore. In: Hinze, J., Boehner, S. \& Lew, J. (Eds). Proceedings of CIB W99 International Conference, $14^{\text {th }}$ Rinker International Conference on Evolution of and Directions in Construction Safety and Health, 9-11 March 2008, Gainesville, Florida, pp. 485-499.

Toole, T. 2002. Construction site safety roles. Journal of Construction Engineering and Management, 128(3), pp. 203-210. https://doi. org/10.1061/(ASCE)0733-9364(2002) 128:3(203)

Vinodkumar, M.N. \& Bhasi, M. 2011. A study on the impact of management system certification on safety management. Safety Science, 49(2011), pp. 498-507. https://doi.org/10.1016/j. ssci.2010.11.009 
Wachter, J.K. \& Yorio, P.L. 2014. A system of safety management practices and worker engagement for reducing and preventing accidents: An empirical and theoretical investigation. Accident Analysis and Prevention, 68(2014), pp.117-130. https://doi.org/10.1016/j. aap.2013.07.029

Wegner, T. 2012. Applied business statistics methods and excel-based applications solutions manual. $4^{\text {th }}$ edition. Cape Town, South Africa: Juta.

Wehbe, F., Hattab, M.A. \& Hamzeh, F. 2016. Exploring associations between resilience and construction safety networks. Safety Science, 82(2016), pp. 338-351. https://doi.org/10.1016/j.ssci.2015.10.006

Wokutch, R. \& VanSandt, C. 2000. OHS management in the United States and Japan: The DuPont and the Toyota models. In: Frick, K., Jensen, P., Quinlan, M. \& Wilthagen, T. (Eds). Systematic OHS management: Perspectives on an international development. Amsterdam: Pergamon, pp. 367-389.

Yankah, K. 2012. Health and safety management practices by building contractors in the Ashanti region. Unpublished Master of Science in Construction Management thesis. Kumasi, Ghana, KNUST: Department of Building Technology.

YU, Q.Z., Ding, L.Y., Zhou, C. \& Luo, H.B. 2014. Analysis of factors influencing safety management for metro construction in China. Accident Analysis and Prevention, 68(2014), pp. 131-138. https://doi. org/10.1016/j.aap.2013.07.016

Zou, P. \& Zhang, G. 2009. Comparative study on the perception of construction safety risks in China and Australia. Journal of Construction Engineering and Management, 135(7), pp. 620-627. https://doi. org/10.1061/(ASCE)CO.1943-7862.0000019 